\title{
MOTIVATION AND RELATIONSHIP OF STUDY HABITS AMONG HIGH SCHOOL STUDENTS- A REVIEW
}

\author{
P. Ramesh $^{1}$ \\ ${ }^{1}$ Department of physical sciences, \\ Sri Sai College of Education, \\ Dornala, Andhra Pradesh, \\ India -523331
}

\author{
K V L N Murthy ${ }^{2}$ \\ ${ }^{2}$ Department of Philosophy, \\ Sri Sai College of Education, \\ Dornala, Andhra Pradesh, \\ India -523331
}

Article DOI: https://doi.org/10.36713/epra3884

\subsection{INTRODUCTION}

Habit can be defined as acquired automatic mechanical and cognitive disposition that is tendencies to behave in a practical way. Study habits are habitual way of exercising and practicing the ability for learning. These are techniques, which students employ to go about his or her studies, which are consistent and have become stereotyped as a result of neither long application nor practice.

Study habits should be logical, dynamic, functional and relevant to the personal characteristics of the individual students. The students approach to learning is highly individualistic with a wide variation of techniques observable. One student may prefer the quite of the library, another student lounge, one may underline text, another takes notes, one may study intensively for several hours, another may take many breaks. The variations are endless, the educationist feels the study process could be more productive if learners were taught specific skills and techniques which would formalize the study process and thereby make it more efficient. Study habits are those activities that are necessary to complete school work task and prepare for taking test. Study habits are those techniques, such as summarizing, note taking, outlining or locating, material which learners employ to assist themselves in the efficient learning of the material at hand. The term 'Study habit' implies a sort of more or less permanent method of studying. Study habits are the essence of a dynamic personality. A proper study habits enables an individual to reap a good harvest in future. Good study habits load to good educational record and bad study habits lead to poor educational record.

Motives are expression of person's need. Hence, they are personal and internal. Incentives on the other hand are external to the person. They are made part of work environment by management in order to encourage workers to accomplish task. The motivational model indicates that a sense of felt deprivation generates needs and such needs create tension in an individual. The individual perceive and makes cost benefit analysis on the ways and means of releasing such tension. Once such perception is cleared, individual pounces upon the activities and achieves some results. If it is success he feels rewarded and falls in the cycle of motivation again. If it is failure he feels punished and once again after due modification of ways and means pounces back on the cycle or feels frustrated. Therefore, motivation leads to a goal directed behavior. Motivation is typically defined as the force that accounts for the arousal, selection, direction and continuation of behaviour. Nevertheless, many teachers have at least two major misconceptions about motivation that prevent them from using this concept with maximum effectiveness. One misconception is that some students are unmotivated. Strictly statement as long as a student chooses goals and expends a certain amount of effort a achieve them, he is by definition, motivated. What teachers really mean is that students are not motivated to behave in the way teacher would like them to behave the second misconception is that one person can directly motivate another.

\subsection{RELATED STUDIES}

A study by Thakkar (2003) investigated into the academic achievement, adjustment and study habit of urban and rural students and concluded that there was no significant relationship between academic achievement and adjustment among rural and urban locality but a positive and significant difference between low and high achieving students in areas of home, family 
personal, educational and health adjustments was observed. Ola and Morakinnyo (2010) concluded that there was significant association between study habit and BFS and found that dimensions of home work and assignment, examination and written work were significant predictors of BFS. These factors should be given consideration when planning any instruction program for students.

Manjuvani and Anuradha (2011) conducted a study to compare the achievement motivation of the children of single parent and two paren families. The sample comprised of 186 students of both the sexes selected purposively for the study. Deo-Mohan achievement motivation scale was used to collect the data results revealed that children of single parent families differed significantly in achievement motivation from the children of two parent families. It was also concluded that parental expectations and guidance developed the need for high achievement. Kaur Kuldip (2014) concluded that academic achievement in Punjabi of $\mathrm{X}$ class students in relation to their level of motivation is positively related.

\subsection{PRESENT STUDY}

The present study would help in finding out the study habits of class $\mathrm{X}$ student. Motivation is arousing interest in learning. Motivation initiates and energies activity in learning. Motivation leads to self actualization in learning. Motivation stimulates learning activity. A person who has high achievement motivation possesses high level of aspiration than those who has weak achievement motive. The persons who have high achievement motivation are more persistent in working at an achievement related task. The persons who have achievement motivation show more efficiency than less motivated persons. The people who have achievement motivation show more anxiety about getting success than the people who are weak in achievement of motive. The persons who have high achievement motivation drive more pleasure from success than those who are weak in achievement motive.

It is very important that students form good study habits. Often, the parents and teachers are at a loss to understand the reason for the discrepancy between the ability of their children and their actual accomplishment. At least part of the contribution to the condition is likely to come from poor study habits since study habits are the sum total of all the habits, determined purposes, and enforced practices that the individual used. In order to learn it is necessary for students to develop special study habits and skills. A well formed habit furnishes its own source of motivation. Good study habits are related with a number of areas, home environment and planning reading and note taking, planning of subjects, concentration, preparation of examination. This study is justified because it will help teachers, parents and students to know the relationship of study habits and motivation.

\subsection{OBJECTIVES AND HYPOTHESES}

$>$ To find whether $\mathrm{X}$ class boys and girls differ in their study habits.

$>$ To find whether $\mathrm{X}$ class boys and girls differ in their level of motivation.

$>$ To find the relationship between study habits and motivation of class X students.

- There exists no significant difference in study habits of boys and girls of class X.

- There exists no significant difference in the level of motivation of boys and girls of class X.

- There exists no significant relationship between study habits and motivation of class X students.

\subsection{RESEARCH DESIGN}

The method of investigation to conduct the present study is essentially descriptive in nature. The study was carried out to see the level of motivation and its and relationship with study habits. The field of investigation was the school students studying in $\mathrm{X}$ class schools affiliated to Krishna District

\subsection{SAMPLE}

For the present study the population was school students. Due to storage of time only the schools of Krishna District were taken. Random sampling was done to select the sample. A sample of 200 students of X class studying in Krishna District board schools was taken.

Showing school wise and sex wise break of the sample. 


\begin{tabular}{|l|c|c|c|c|}
\hline Name of the School & Class & No. of Boys & $\begin{array}{c}\text { No. of } \\
\text { Girls }\end{array}$ & \begin{tabular}{c} 
Total \\
\hline Govt. Senior Secondary School Boys,
\end{tabular} \\
\hline Govt. Senior Secondary School Girls & Xth & - & - & 80 \\
\hline Govt. Senior Secondary School, & Xth & 80 & - & 80 \\
\hline Govt. Senior Secondary School & Xth & - & 80 & 80 \\
\hline Total & & $\mathbf{1 6 0 + \mathbf { 1 6 0 }}$ & $\mathbf{3 2 0}$ \\
\hline
\end{tabular}

Tools

For present study the following tools were used:

1. Dr. B.V. Patel Study-Habits Inventory, 2. Rao achievement Motivation Test.

\subsection{STATISTICAL TECHNIQUES}

In order to interpret the data and to draw meaningful conclusions the data should be analyzed with the help of (i) Mean, (ii) Median, (iii) Standard deviation, (iv) Correlations, (v) t-test.

\subsection{CONCLUSIONS AND FINDINGS}

- The educational implications of the study are that the parents and teacher can help in the development of motivation level, by creating a conductive environment for the development of motivation level among the adolescents.

- This will help in the improvement in study habits of the students. So the motivation programs should be organised for adolescent students.

- This program will be beneficial and helpful to adolescent student in improving their motivation level and also improving in study habits.

- It helps them to continue their study with positive motivation, behaviour, furthermore positive study habits.

- By having good study habits students should motivated to learn.

\subsection{REFERENCES}

1. Kaur, K. (2014). Academic achievement in Punjabi of Xth class students in relation to their level of motivation. An M.Ed. Thesis submitted to Guru Nanak Dev University, Amritsar.

2. Manjuvani and Anuradha, K. (2011). Achievement motivation of children of single parent and two parent families. Journal of Community Guidance and Research, 28(1): 147-153.

3. Ola, A.B. and Morkainyo, O. (2010). Study habits among Nigerian secondary school students with brain fog syndrome. Retrieved on May 11, 2012, http://www.pagepress.org/journal/indexphp/nni/article/view/uni.2010.e2/1849

4. Thakkar, P.D. (2003). A study of academic achievement adjustment and study habits of rural and urban students. Ph.D. (Education) University of Mumbai. In Sansanwal, D.N. (Ed.), Sixth Survey of Research in Education, 1992-2006. 